\title{
Beneath the Basilica of San Marco: new light on the origins of Venice
}

\author{
Albert J. Ammerman ${ }^{1, *}$, Charlotte L. Pearson ${ }^{2}$, Peter I. Kuniholm², \\ Bruce Selleck ${ }^{3} \&$ Ettore Vio ${ }^{4}$
}

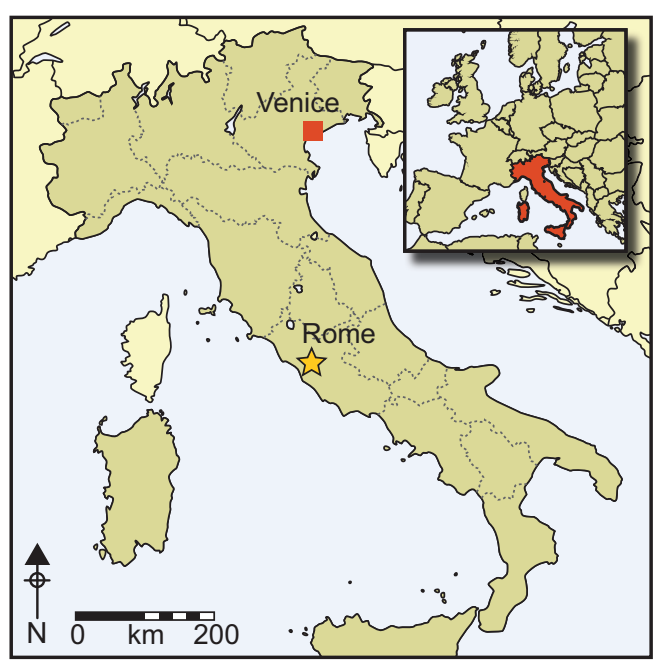

The origins of Venice have been of great interest to Venetians and to scholars more generally for centuries. Long shrouded in myth and legend due to the dearth of pre-ninth-century $A D$ evidence, recent archaeological research is now illuminating how the famous city built on water began. Using high-resolution AMS dating of peach stones (pits) from below the Basilica of San Marco, the authors provide the first evidence for human activity at what is now the location of Piazza San Marco. Dating to between $A D 650$ and 770, this activity included canal in-filling and ground consolidation intended to create an area that was to become the city's civic centre in the early ninth century.

Keywords: Venice, Piazza San Marco, Basilica of San Marco, AMS dating

\section{Introduction}

The question of how Venice, the city built on water, began is one of great interest to both the Venetian and the scholar. Over the centuries, writers have spent much time and effort attempting to tell the story of the origins of the city, from those writing in the Venetian chronicle tradition with its share of fanciful legends (Carile \& Fedalto 1978; Brown 1991) to the modern historians offering a more critical perspective (e.g. Nicol 1988; CraccoRuggini et al. 1992; Crouzet-Pavan 1999). Even the best attempts as yet proposed are, however, limited in their scope and detail. The problem has always been the dearth of relevant first-hand documents from before the ninth century AD (Cessi 1942; Ortalli 1981;

\footnotetext{
Department of the Classics, Colgate University, Lawrence Hall, 13 Oak Drive, Hamilton, NY 13346, USA Laboratory of Tree-Ring Research, University of Arizona, 1215 E Lowell Street, Tucson, AZ 85721, USA Department of Geology, Colgate University, Ho Science Center, 13 Oak Drive, Hamilton, NY 13346, USA Proto di San Marco, San Marco 328, 30100 Venice, Italy

Author for correspondence (Email: aammerman@colgate.edu)
} 
Agazzi 1991; Ammerman 2003). The Basilica of San Marco (Demus 1990; Polacco 1997; Wolters 2014) is located on the east side of Piazza San Marco (Figure 1). It is, of course, one of the great historical monuments of Europe. Now, archaeological finds from deep beneath the Basilica are opening a new window on what was taking place at Piazza San Marco before the construction of the Basilica.

According to Venetian tradition, the bones of Saint Mark the Evangelist were brought from Alexandria to Venice in AD 828, and the first Basilica in honour of him was dedicated four years later. A few years earlier, in $\mathrm{AD} 810$ or 811, another important event in Venetian history had taken place: the seat of the Doge was moved from Malamocco on the Lido to Piazza San Marco. At this time, the new town that was emerging on the archipelago of small marsh islands in the middle of the Venetian Lagoon was called Rivoalto, and not Venice. The discovery and the dating of two peach stones recovered from a deep core beneath the Basilica now provide key evidence for the 'pre-history' of Piazza San Marco (for our previous work there, see Ammerman et al. 1995: 504-509; Ammerman \& McClennen 2001: 2425).

Compared to other great historical cities of Europe, urban archaeology had a late start in Venice. Here, the challenge for the archaeologist is the high water table. As recently as 1983, no archaeological site within the area of the city had been excavated using modern methods. This was achieved for the first time at two early Venetian sites in the late 1980s: San Pietro di Castello (Tuzzato 1991) and San Lorenzo di Castello (De Min 2000a). In 1990, Maurizia De Min, the archaeologist in charge of excavations conducted at Venetian monuments, invited the first author to make a series of cores below the ninth-century church of San Lorenzo, which proved highly productive (see Ammerman et al. 1992: 913-16). Over the next 12 years, De Min and Ammerman worked in close collaboration at many other sites across the city and the lagoon, including the Marciana Library, the Ducal Palace, the Frari, San Francesco del Deserto and Torcello. In 1993, three deep cores were taken beneath the Marciana Library on the south side of the Piazza (M1 in Figure 1; Ammerman et al. 1995: 504-507; Ammerman 1997: 91-93). In the same year, the opportunity arose to study deep cores taken at six different places in the Piazza (S1-6 in Figure 1). Both the Marciana Library and Piazza cores are discussed below.

This first cycle of work brought three innovations to the investigation of early sites in Venice. First, coring was carried out during the initial phase of the fieldwork at a new site. For this, we designed and produced coring equipment suitable for the local conditions in Venice (Ammerman \& McClennen 2001: 32). The intention was to target our excavation based on data from the coring. The parallel here is with modern surgical biopsy. Second, the then new method of accelerator mass spectrometry (AMS) was used to radiocarbondate samples of reeds and wood recovered from the cores taken at the early sites (e.g. Ammerman \& McClennen 2001: 22-23). AMS allowed the dating of smaller, higherquality samples. It was used for the first time in Venice at the site of San Lorenzo di Castello, in 1992 (Ammerman et al. 1992: 915, tab. 1). Over the following two years, a series of AMS dates was produced at San Francesco del Deserto (five dates in the fifth and sixth centuries $\mathrm{AD}$ ) and at the Marciana Library (five dates in the seventh and eighth centuries AD) (Ammerman et al. 1995: 501-504, tab. 1). The latter were the first ${ }^{14} \mathrm{C}$ dates from before the ninth century at Piazza San Marco. Thirdly, we undertook environmental studies 


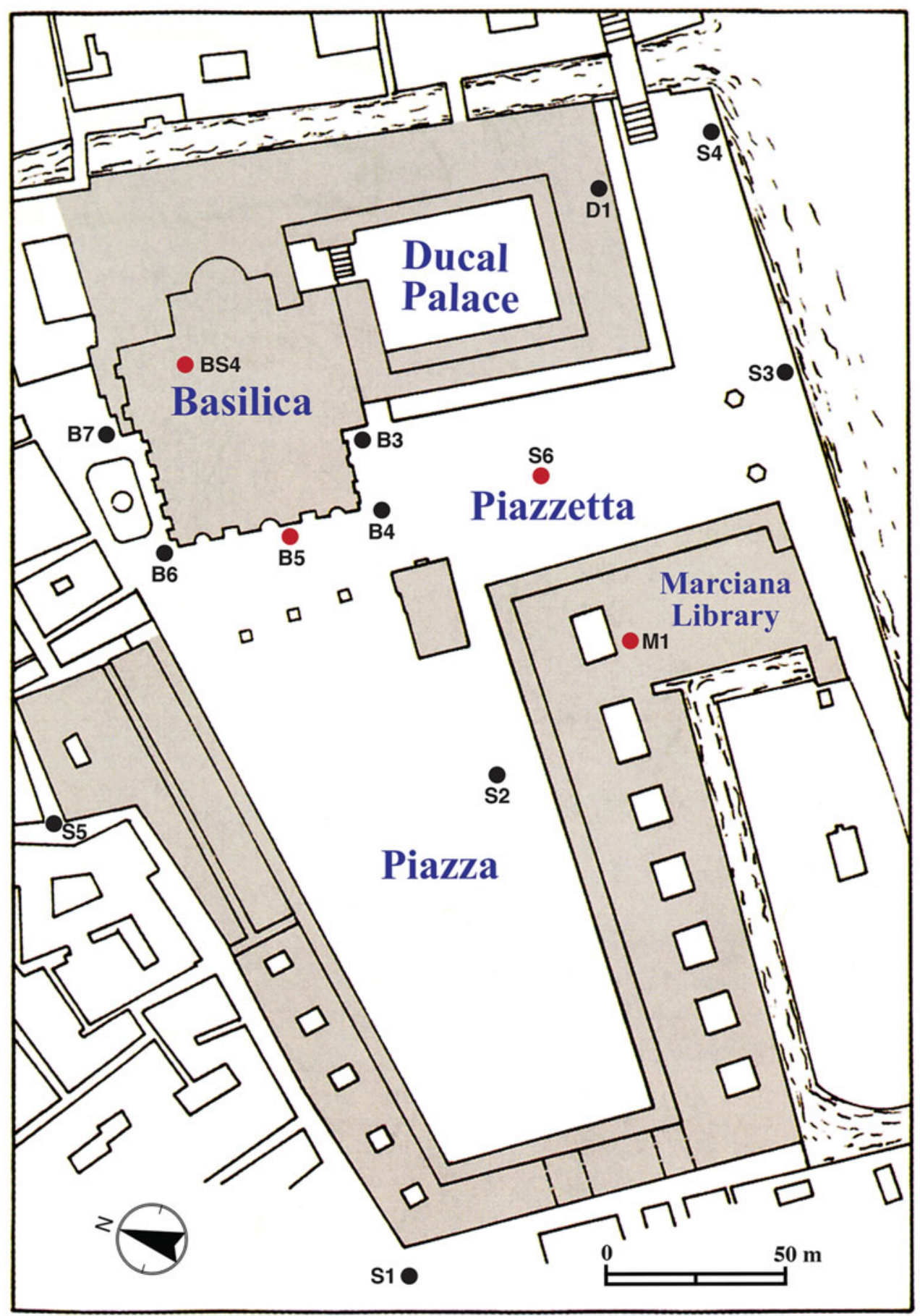

Figure 1. Map showing the location of the cores at four sites in Piazza San Marco that have produced radiocarbon dates to before the ninth century AD: 1) Marciana Library (M1);2) the Piazzetta in front of the Ducal Palace (S6); 3) the area of the Piazza in front of the main door of the Basilica (B5); and 4) the interior of the Basilica of San Marco (BS4).

(C) Antiquity Publications Ltd, 2017 
in the lagoon by combining sub-bottom profiling and coring from a boat. When we first went to Venice, there was much uncertainty in the literature concerning the position and the dating of the important boundary at the base of the lagoon. The fieldwork, which was carried out in 1993 and 1994, established the position of the boundary, which was located as being 4.5-6m below modern sea level (Ammerman et al. 1995: 506-507; McClennen et al. 1997: 755-58, fig. 9; Ammerman et al. 1999: 305, fig. 2). AMS dating of plant fibre samples from cores taken at the boundary dated it to between 5000 and 6000 years old (Ammerman et al. 1995: 507, 1999: 306-309, tab. 1; McClennen et al. 1997: 753). These new results were then confirmed by subsequent investigations in the Venetian Lagoon (Serandrei-Barbero \& Donnici 2013).

Research progressed well from one site to the next during the first ten years of our work in Venice, although frustration and disappointment were experienced at the Basilica of San Marco. Work there began in 2000 at the invitation of Roberto Cecchi, Superintendent of Monuments of the Veneto region, who was planning to write a book on the Basilica (Cecchi 2003). Our task was to study several cores to obtain samples of wood for species identification and dating. The cores started at the mosaic floor of the Basilica and went down through its foundations to the natural soil below. Ettore Vio, Proto of San Marco (the architect in charge of the Basilica), had commissioned a firm in Bergamo to take the cores. While the cores were of good quality, basic pieces of information were missing from their documentation, such as the lack of starting elevations and technical drawings for each core. These presented serious limitations to the study of the cores from the church interior, and effectively halted our research at the most important site in Piazza San Marco.

\section{Returning to Piazza San Marco}

In 2014, an unexpected turn of events led to our return to Piazza San Marco. Ettore Vio, still the Proto of San Marco, and our old friend, produced high-quality drawings of 73 cores and a detailed map of the mosaic floor with the missing elevations. We examined all of the core drawings, and the most promising one, core BS4, did not disappoint. In October of 2015, the opportunity arose to examine and sample the cores themselves. At depths of 4.18 and $4.16 \mathrm{~m}$ in core BS4, two whole peach stones were found adjacent to each other. They were recovered from the context of an anthropic sediment—one linked with the in-filling of a canal (this is discussed below).

The short life (one year) of a peach stone, along with its abundance of ${ }^{14} \mathrm{C}$, makes it an ideal sample for AMS dating. In addition, the presence of two peach stones meant that the quality of the dates obtained could be assessed. Dating was undertaken at the University of Arizona, where results with low standard deviations were obtained: respectively, 25 years for fruit stone 1 (X29596) and 21 years for fruit stone 2 (X29597; Figure 2; see online supplementary material (OSM) on the dating of the two peach stones and also a third sample - a nearby fragment of elm charcoal, X29589). The three samples were in close agreement, yielding calibrated ages dating to between AD 650 and 770 (at the 95\% confidence level). It should be mentioned that each sample pre-dates the AD 828 arrival of the relics of Saint Mark in Venice by at least two generations. These three high-resolution dates have provided the missing piece in the puzzle concerning the area below the Basilica. 


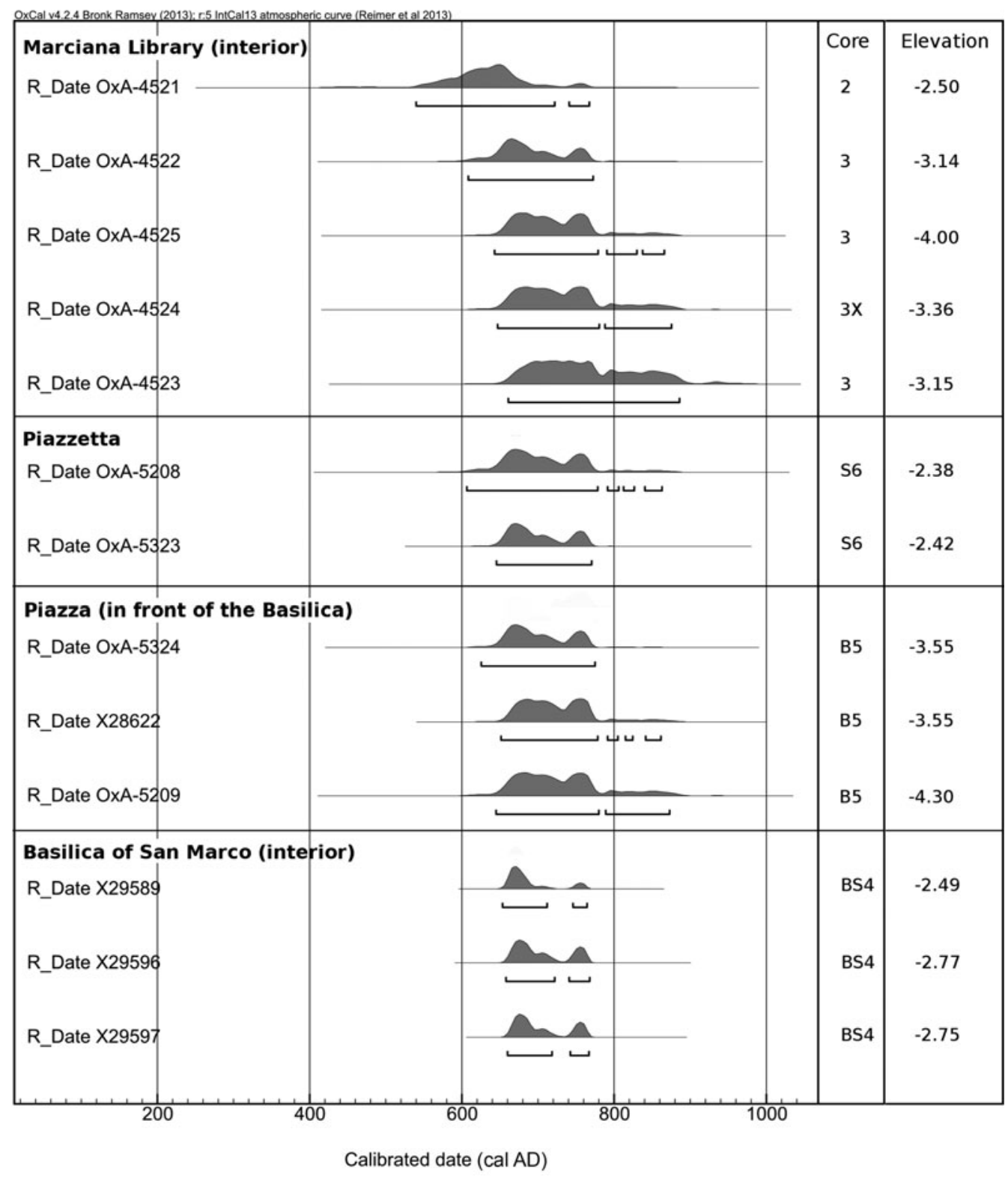

Figure 2. The calibrated ages of radiocarbon dates obtained for the four early sites at Piazza San Marco: 1) Marciana Library (M1); 2) the Piazzetta (S6); 3) the area of the Piazza in front of the main door of the Basilica (B5); and 4) the interior of the Basilica of San Marco (BS4). The rightmost column gives the elevations of the dated samples. Dates calibrated in OxCal v4.2 using the IntCal13 curve (Bronk Ramsey 2009; Reimer et al. 2013).

There is a clear pattern to the dates in Figure 2: they all cluster in the seventh and eighth centuries (AD 600-800), providing evidence at each of the four sites for human activity predating San Marco. Conversely, they provide little or no support for local human activity in the sixth century $\mathrm{AD}$, with the possible exception of the sample OxA-4521 from the (C) Antiquity Publications Ltd, 2017 


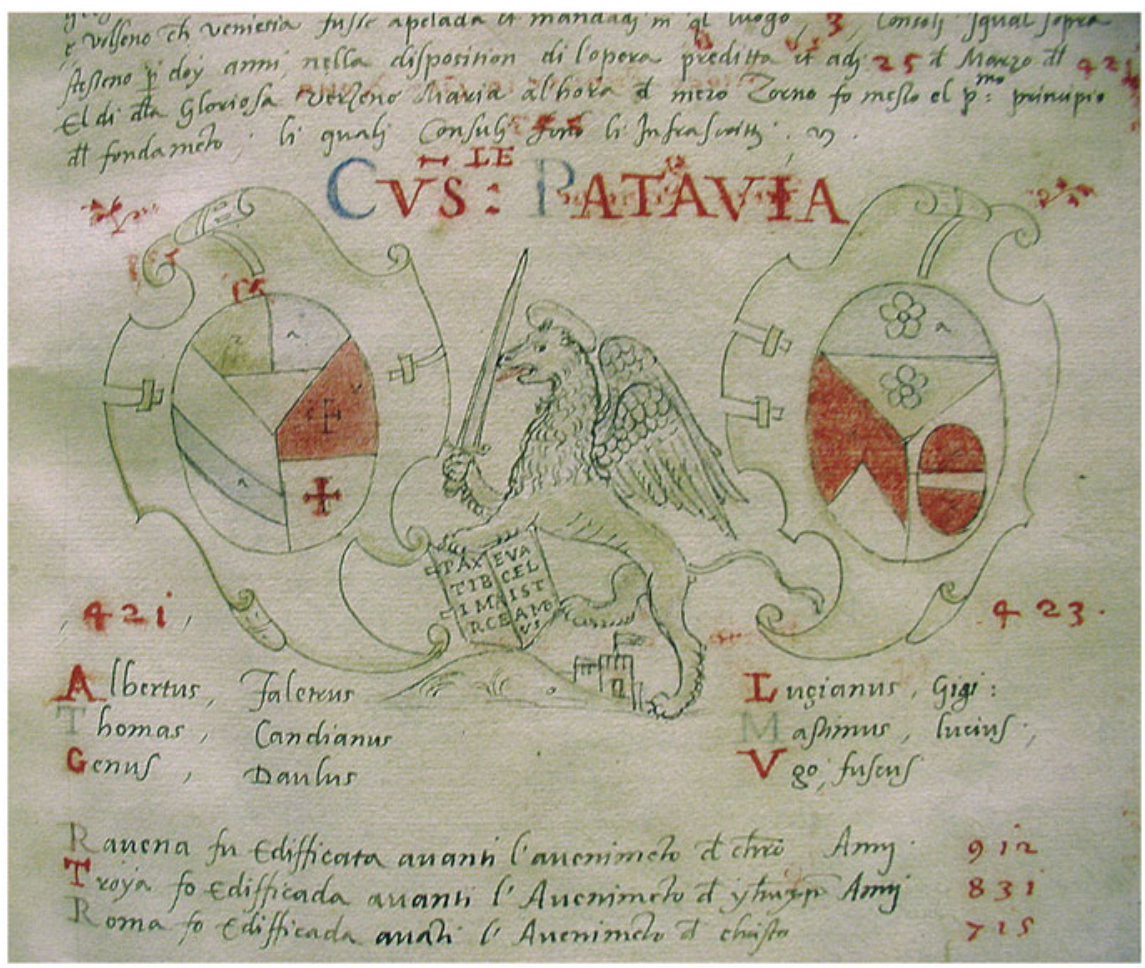

Figure 3. The legendary foundation of Venice as a city by three consuls from Padua in $A D 421$, as portrayed in the manuscript Chronicon venetum ab origine ad an MDLIX. This Venetian chronicle is now in the Ranke Collection of the Syracuse University Library.

Marciana Library (Figure 2). The widths and shapes of the probability curves in Figure 2 are influenced by the standard deviations of the respective dates. For the first three sites, their values are consistently larger (in the range of 60-40 years; for more information on each dated sample, see Table S1 in the OSM) than the standard deviations of the new dates from below the Basilica (in the range of 25-21 years). The higher resolution of these three AMS dates provides a new level of chronological refinement for early Venice. The elevations of the samples in Figure 2 show that they all came from depths of between -2.38 and $-4.3 \mathrm{~m}$ below modern sea level (in Venice, sea level is commonly measured with reference to the 1897 tide-gauge standard). We have reconstructed the curve for the rise in relative sea level of the Venetian Lagoon over the last 18 centuries (Ammerman et al. 1999: fig. 3; Ammerman 2005: fig. 13.2) and estimate that the level was approximately $-2 \mathrm{~m}$ in elevation in the second century AD. By the eighth century, it had risen to an elevation in the range of -1.6 to $-1.4 \mathrm{~m}$. Hence, all the dated samples in Figure 2 come from positions that were below sea level in the seventh and eighth centuries. The inference is, therefore, that all the dated samples are linked with the in-filling of canals at that time.

Four small pieces of mortar were observed in the sediments of the three cores from the Marciana Library, along with reeds, and six different species of wood, including oak and elm (Ammerman et al. 1995: 509, tab. 2). Core S6 in the Piazzetta also yielded archaeological 
inclusions, including a dated wood chip at $-2.38 \mathrm{~m}$ in elevation (OxA-5208), a dated animal bone at $-2.42 \mathrm{~m}(\mathrm{OxA}-5323)$ and several small pieces of early glass at $-2.4 \mathrm{~m}$. Core B5 was taken in the Piazza as one of the cores around the Basilica commissioned by Vio in the early 1990s. It was then sampled during work on our own series of six deep cores in the Piazza (S1-6). Located in front of the main door of the Basilica, core B5 produced two good-sized pieces of wood, including elm at $-3.55 \mathrm{~m}$ in elevation (OxA-5324 and X28622; both dates were run on the outer rings of the sample) and oak at $-4.3 \mathrm{~m}$ (OxA-5209). The depths of these two samples should be noted, with the implication that they came from a canal of reasonable size. Of relevance to the two peach stones in core BS4 (recovered respectively at -2.77 and $-2.75 \mathrm{~m}$ in elevation) is a review article (Sadori et al. 2009) on the introduction of the peach to Italy, and the spatial distribution of peach stones at Italian archaeological sites. According to the authors, peaches were introduced into Italy during Roman times (the first half of the first century AD), and by the seventh century AD, peach trees had become well established in northern Italy. Our SEM/EDS examination of the grainy sediment found in association with the two fruit stones has shown that the sediment is anthropic. As documented in the OSM, the following features were observed in the sediment sample: 1) one definite ceramic fragment (slide number 8 , based on the relative peak heights for the elements aluminium, silicon and potassium); 2) four possible ceramic fragments (numbers 3, 5, 10 and 14); 3) one seed (number 9); 4) two angular grains of quartz of fair size (numbers 10 and 13); and 5) one grain of zinc metal (number 15).

\section{Discussion}

When considering the wider implications of these new results for the origins of Venice, our high-resolution dating of samples to the second half of the seventh century and the first half of the eighth century is particularly striking. Taken together with the dates from the other three sites (Figure 2), we can conclude that the prehistory of the area of what would be the future Piazza San Marco had a rather shallow time-depth-one that spans only a few human generations. This is in marked contrast with the situation in the northern lagoon, where Roman occupation is well documented at sites such as Torcello (Leciejewicz et al. 1977; De Min 2000b). Excavations there revealed a tile structure dating to the second century $\mathrm{AD}$, the architectural remains of a small room with brick walls dating to the fifth century, and also two small wooden houses, each with a hearth dating to the sixth century (Ammerman \& McClennen 2001: 16-17; for information on a nearby small wooden warehouse contemporaneous with the two houses, see Calaon 2015: fig. 4 and references therein). Torcello is, of course, well known for its early Basilica, which was dedicated to Saint Mary the Mother of God in AD 639. One explanation for the late start of Venice is its location in the middle of the lagoon, and not in the vicinity of the two main lines of communication in Roman times (Bellavista \& Romanelli 1985: 17; Ammerman 2003: 155). The first began at the inlet of the Adriatic Sea and passed near the island of Torcello on its way to the Roman town of Altinum, and then via the Sile River to the Roman town of Travisium (Treviso). The second line of communication passed to the south of Venice, where it was directed towards the Brenta River and the Roman town of Patavium (Padua).

(C) Antiquity Publications Ltd, 2017 
Most of the great historical cities in Italy do have Roman roots, and this was something that the Venetians naturally longed for. Support for this idea is not, however, found in ancient sources, and there are no extant standing Roman ruins within the city. Yet this did not stop the Venetian chroniclers from inventing such roots. According to Venetian myth, the city was founded by three consuls from Padua in AD 421 (Figure 3), a legend that made its first appearance in the Chronicon Altinate (AD 1081-1204). This foundation date was then reified in stone when the Arsenal Portal was built in 1460 (Brown 1996: 108-10). For many years, the Venetians remained attached to this as the date of the foundation of their city. Even during the twentieth century, scholars (e.g. Dorigo 1983) continued to argue for Roman roots, regardless of the lack of reliable archaeological evidence dating to the time before the sixth century. It should be noted here that Tuzzato's (1991: 92-103) claim that occupation at San Pietro di Castello dates back to the fifth century AD is no longer accepted. More recently, Marco Bortoletto returned to the area of the site where Tuzzato dug, took the excavation to a greater depth and demonstrated that the oldest levels date to no earlier than the sixth century AD (Bortoletto pers. comm.).

The Roman town located closest to Venice- $12 \mathrm{~km}$ to the north-was Altinum on the mainland, behind the lagoon (Tirelli 2011). The plan of the Roman town was, however, poorly understood until the first decade of the present century, when remote sensing finally revealed its layout (Ninfo et al. 2009). For years, the idea persisted that Roman Altinum had an environmental setting akin to that of Venice. Recent coring has, however, provided evidence to refute this old idea; coring revealed that Roman Altinum was built on an earlier anthropic mound (around $2 \mathrm{~m}$ high), which rested, in turn, on old terrestrial soils, rather than the soft marine (lagoonal) sediments upon which Venice was built (Ammerman 2012: 698-99).

For those who live in a great city, it is heartening to think that their city had a great start too. Had its start been a modest or uneventful one, there would be little in the remote past to celebrate and to give its citizens a sense of identity (Brown 1991). The worst case would be for a city to have a late start and a modest one as well. This is just the position that the Venetians found themselves in, and, over the centuries, they tried to address the problem in two ways. The first was to invent legends, such as the founding of the city by three consuls from Padua - thereby conferring Roman roots on their city. The other strategy was to claim that their city began simply from a clean slate; there was nothing to be gained by having a modest eighth-century start at a place called Rivoalto. Accordingly, as events of the eighth century were played down by the Venetians and largely forgotten, the following century was far more memorable (Ammerman 2003: 147). As part of a concerted effort to keep the slate clean prior to San Marco, the Venetians chose to suppress the significance of the early Basilica on the island of Torcello (Crouzet-Pavan 2017). And while the relocation of the ducal seat from Malamocco to Venice was a major event, there was no room on the walls of the Sala dello Scrutino in the Ducal Palace to hang the portraits of the Doges who ruled at Malamocco in the eighth century (Ammerman 2011: 268).

There was, in short, much ambivalence concerning the origins of Venice. While there was the notion that the city had Roman roots, there was also the idea that the guiding hand of providence had made it possible for the city to arise from a tabula rasa. But neither stance was correct. As we now know, the city's civic centre did not start from a clean slate. 
Piazza San Marco did have a prehistory in the seventh and eighth centuries, and one that Roman grandeur played no part in. Instead, what was involved was the low-profile work of consolidating the ground and in-filling of the canals that once meandered through the area. By transforming the landscape of what had previously been a marginal place, it was possible to create a large, contiguous space where the new civic centre was established in the ninth century. It is important to recall here that landscape transformation has recently emerged as a new theme in the archaeology of early Rome (e.g. the reclamation of land in the case of the Forum) and of the high Carolingian age (e.g. the construction of terraces as a feature of the architectural rhetoric). It is not, however, possible to detail here the human transformation of the landscape in such parallel cases. In this article our interest is in the age-old question of how the city of Venice began. We have provided a new line of interpretation to reflect upon and to explore further; the task of the modern archaeologist here then is to provide substantive evidence in order to promote relevant discourse on the origins of Venice.

\section{Acknowledgements}

The research was supported by grants from the Delmas Foundation, Colgate University, the Kress Foundation and the National Geographic Society. For their assistance in the recent fieldwork, our appreciation goes to Ivana Pezzo and Stefano Marconi of the Laboratory of Dendrochronology at the Museo Civico in Rovereto, Italy. For the high-resolution dating of the two peach stones, we wish to thank Greg Hodgins at the AMS Laboratory of the University of Arizona.

\section{Supplementary material}

To view supplementary material for this article, please visit https://doi.org/10.15184/aqy. 2017.164

\section{References}

Agazzi, M. 1991. Platea Sancti Marci. Venezia: Comune di Venezia.

Ammerman, A.J. 1997. Assaggi archeologici nell'area della Libreria Sansoviniana, in R. Polacco (ed.) Storia dell'arte marciana: l'architettura: 88-94. Venezia: Marsilio.

- 2003. Venice before the Grand Canal. Memoirs of the American Academy in Rome 48: 141-58. https://doi.org/10.2307/4238806

-2005 . The third dimension in Venice, in C. Fletcher \& T. Spencer (ed.) Flooding and environmental challenges for Venice and its lagoon: 107-15. Cambridge: Cambridge University Press.

- 2011. Relocating the center: a comparative study, in N. Terrenato \& D.C. Haggis (ed.) State formation in Italy and Greece. Questioning the neoevolutionist paradigm: 256-72. Oxford: Oxbow.

- 2012. Altinum and early Venice. Journal of Roman Archaeology 25: 696-703.

Ammerman, A.J. \& C.E. McClennen. 2001. Venice before San Marco. Recent studies on the origins of the city. Hamilton (NY): Colgate University.
Ammerman, A.J., M. De Min \& R. Housley. 1992. New evidence on the origins of Venice. Antiquity 66: 913-16. https://doi.org/10.1017/S0003598X00044823

Ammerman, A.J., M. De Min, R. Housley \& C.E. McClennen. 1995. More on the origins of Venice. Antiquity 69: 501-10. https://doi.org/10.1017/S0003598X00081898

Ammerman, A.J., C.E. McClennen, M. De Min \& R. Housley. 1999. Sea-level change and the archaeology of early Venice. Antiquity 73: 305-12. https://doi.org/10.1017/S0003598X00088268

Bellavista, G. \& G. Romanelli. 1985. Venezia: la città nella storia d'Italia. Roma: Laterza.

Bronk Ramsey, C. 2009. Bayesian analysis of radiocarbon dates. Radiocarbon 51: 337-60. http://dx.doi.org/10.2458/azu_js_rc.51.3494

Brown, P.F. 1991. Self-definition of the Venetian Republic, in A. Molho, K. Raaflaub \& J. Emlen (ed.) City-states in Classical antiquity and medieval Italy: 511-48. Ann Arbor (MI): University of Michigan Press.

- 1996. Venice and antiquity. New Haven (CT): Yale University Press.

(C) Antiquity Publications Ltd, 2017 
Calaon, D. 2015. Tecniche edilizie, materiali da costruzione e società: leggere gli spolia nel contesto archeologico, in A. Centanni \& L. Sperti (ed.) Pietre di Venezia. Spolia in se, spolia in re: 85-111. Roma: 'L'Erma' di Bretschneider.

Carile, A. \& G. Fedalto. 1978. Le origini di Venezia. Bologna: Pàtron.

Cecchi, R. 2003. La Basilica di San Marco. La costruzione Bizantina del IX secolo. Venezia: Marsilio.

Cessi, R. 1942. Documenti relativi alla storia di Venezia anteriori al mille. Padova: Gregoriana.

Cracco-Ruggini, L., M. Pavan, G. Cracco \& G. Ortalli (ed.). 1992. Origini. Età Ducale. Storia di Venezia. Roma: Enciclopedia Italiana.

Crouzet-Pavan, E. 1999. Venise triomphante: les horizons d'un mythe. Paris: Albin Michel.

- 2017. La mort lente de Torcello: histoire d'une cité disparue. Paris: Fayard.

De Min, M. 2000a. Venezia. Chiesa di San Lorenzo di Castello: un esempio di scavo correlato al restauro archiettonico, in Ritrovare restaurando. Rinvenimenti e scoperte a Venezia e in laguna: 40-70. Venezia: Soprintendenza per i Beni Ambientali e Architettonici di Venezia.

- 2000b. Edilizia altomedioevale e medioevale nel territorio lagunare, in Tra due elementi sospesa. Venezia, costruzione di un paesaggio urbano: 99-119. Venezia: Marsilio.

Demus, O. 1990. The Church of San Marco in Venice. Washington, D.C.: Dumbarton Oaks.

Dorigo, V. 1983. Venezia origini. Milano: Electa.

Leciejewicz, L.E., E. TABaczynska \& M. Tabaczynski. 1977. Torcello: Scavi 1961-62. Roma: Fondazione Giorgio Cini.

McClennen, C.E., A.J. Ammerman \& S. Schock. 1997. Framework stratigraphy for the Lagoon of Venice, Italy: revealed by new seismic-reflection profiles and cores. Journal of Coastal Research 13: 745-59.
Nicol, D.M. 1988. Byzantium and Venice. Cambridge: Cambridge University Press.

Ninfo, A., A. Fontana, P. Mozzi \& F. Ferrarese. 2009. The map of Altinum, the ancestor of Venice. Science 325: 577. https://doi.org/10.1126/science.1174206

Ortalli, G. 1981. Il problema storico delle origini di Venezia, in Le origini di Venezia: 85-89. Venezia: Marsilio.

Polacco, R. (ed.). 1997. Storia dell'arte Marciana: l'architettura. Venezia: Marsilio.

Reimer, P.J., E. Bard, A. Bayliss, J.W. Beck, P.G. Blackwell, C. Bronk Ramsey, C.E. Buck, H. Cheng, R.L. Edwards, M. Friedrich, P.M. Grootes, T.P. Guilderson, H. Haflidason, I. Hajdas, C. Hatté, T.J. Heaton, D.L. Hoffmann, A.G. Hogg, K.A. Hughen, K.F. Kaiser, B. Kromer, S.W. Manning, M. Niu, R.W. Reimer, D.A. Richards, E.M. Scott, J.R. Southon, R.A. Staff, C.S.M. Turney \& J. van der Plicht. 2013. IntCal13 and Marine13 radiocarbon age calibration curves $0-50,000$ years cal BP. Radiocarbon 55: 1869-87. http://dx.doi.org/10.2458/azu_js_rc.55.16947

Sadori, L., E. Allevato, G. Bosi, G. Caneva, E. Castiglioni, A. Celant, G. Di Pasquale, M. Giardini, M. Mazzanti, R. Rinaldi, M. Rottoli \& F. Susanna. 2009. The introduction and diffusion of peach in ancient Italy, in J.-P. Morel (ed.) Plants and culture: seeds of the cultural heritage of Europe: 45-61. Bari: Edipuglia.

Serandrei-Barbero, R. \& S. Donnici. 2013. Le età della Laguna. Venezia: Corte del Fontego.

Tirelli, M. (ed.). 2011. Altino antica: Dai Veneti a Venezia. Venezia: Marsilio.

Tuzzato, S. 1991. Venezia. Gli scavi a San Pietro di Castello (Olivolo). Nota preliminare sulle campagne 1986-1989. Quaderni di Archeologia del Veneto 7: 92-103.

Wolters, W. 2014. San Marco a Venezia. Verona: Cierre.

Received: 7 October 2016; Accepted: 9 January 2017; Revised: 25 January 2017

(C) Antiquity Publications Ltd, 2017 